$\left(\begin{array}{llr}\text { Jpn. } & \text { J. Hosp. } & \text { Pharm. } \\ \text { 23(6) } & 548-552 & (1997)\end{array}\right)$

\title{
ラットにおけるフレロキサシンとバルプロ酸の相互作用
}

\author{
芳原準男, 亀谷浩昌, 外間惟夫, 大城 進 \\ 琉球大学医学部附属病院薬剤部, 地域医療研究センター†
}

\section{Pharmacokinetic Interaction of Fleroxacin and Sodium Valproate in Rats}

\author{
NORIO HOBARA, HiROMASA KAMEYA, NOBUO HOKAMA and SUSUmU OHSHIRO \\ Department of Hospital Pharmacy and Research of Comprehensive Medicine, \\ Faculty of Medicine, Ryukyu University $\dagger$
}

$\left(\begin{array}{lc}\text { Received January 30, } & 1997 \\ \text { Accepted August 25, } & 1997\end{array}\right)$

The plasma concentration of fleroxacin (FLRX) was significantly lower $(P<0.05)$ than the control at 0.5 and 1 hour but was significantly $(\mathrm{P}<0.05)$ higher at 4, 8, 12 and 24 hurs after the simultaneous oral administration of FLRX with sodium valproate (VPA). The pharmacokinetic parameters, the volume of distribution $(\mathrm{Vd})$ and the area under the plasma concentration-time curve from 0 to 24 hours $\left(\mathrm{AUC}_{0 \rightarrow 24}\right)$ were 1.2-and 2.3-times higher, while the elimination half-life $\left(\mathrm{T}_{1 / 2}\right)$ and time to maximum plasma concentration $\left(\mathrm{T}_{\max }\right)$, were delayed by 2.9 -and 2.6 -times after the simultaneous administration with VPA and all changes were significant $(\mathrm{P}<0.05)$. In addition, the absorption rate constant $(\mathrm{Ka})$ and clearanse $(\mathrm{CL})$ were, in contrast, 0.5 and 0.5 times lower than the control, and the difference was also significant $(\mathrm{P}<0.05)$. The unbound flaction (\%) of FLRX in the plasma increased 54 to $80 \%$ at 2 minutes and to $76 \%$ at 15 minutes after the intravenous administration of VPA. On the other hand, the total levels of FLRX decreased by 31.9 and $27.7 \%$ at 2 and 15 minutes after the intravenous administration of VPA, respectively. The urinary concentration of FLRX, demethyl-FLRX and FLRX N-oxide decreased by 50, 40 and $50 \%$, respectively, at 8 hours after the intravenous administration of VPA. These results that VPA may decrease the protein binding and inhibit the metabolic rate of FLRX simultaneously, when they are administered concurrently.

Key words - fleroxacin, demethyl fleroxacin, fleroxacin $\mathrm{N}$-oxide, sodium valproate, pharmacokinetic drug interaction, protein binding, inhibition of drug metabolism

\section{緒言}

6,8-difluoro-1-(2-fluoroethyl)-1,4-dihydro-7(4-methyl-1-piperazinyl ) -4-oxo-3-quinolinecarboxylic acid（Fleoxacin, FLRX）は広い抗菌力

$†$ 沖縄県中頭郡西原町字上原 $207 ; 207$, Uehara, Nishihara-cho, Okinawa, 903-01, Japan
を有し，グラム陽性及びグラム㓌性菌に対して有 効な 11 キノロンカルボン酸誘導体のニューキノ ロン剤である。経い投与による吸収が良好で，既 存のニューキノロン剤に比べ, 薬剮投与後の最高 血中濃度 $\left(\mathrm{C}_{\max }\right)$ は高く, 血中半減期 $\left(\mathrm{T}_{12}\right)$ が 長く2), 組織移行性が良好な薬郕である ${ }^{3 \prime}$ 。 ニューキノロンは $\mathrm{C}_{\max }$ と血俋中濃度一時間曲線下面 
積（AUC）が人きいほど殺阑效果が堌強する反 面。间時に椡作朋の频度も高くなる川能性が指摘 されている゙。.

バルプロ酸（VPA）は公範な発作抑制スペクト

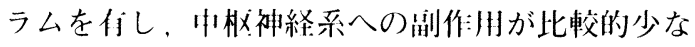

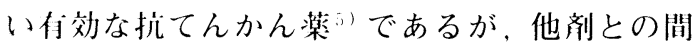
に複雑な相 $I$. 作用が数多く忍められている。ま た，バルプロ酸でてんかんの発作をコントロール している患者が呼吸器や水路等の感染症に疾患し た場合、VPAとFLRXの併用が考えられる。著

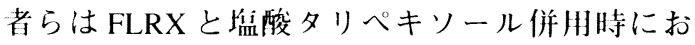
けるFLRXの薬物代謝動態について検吘を加え てきだ!。今间はFLRXとVPA间時投少後の FLRXの薬物動態を検討したので報告する。

\section{方法}

FLRX , 6,8-difluoro-1-(2-fluoroethyl)-1,4-dihydro-7-(1-piperazinyl)-4-oxo-3-quinolinecarboxylic acid (demethyl fleroxacin, demethyl FLRX) ,6,8 -difluoro-1-(2-fluoroethyl) -1,4-dihydro-7 (4methyl-4-oxide-1-piperazinyl)-4-oxo-3-quinolinecarbxylic acid (flerxacin N-oxde, FLRX N-oxide) は杏林製薬から供与を受けた。VPAは協和発酵 工. 業のデパケンシロップ ( $5 \%$ Sodium Valproate）と協和発酵工業から供与を受けた sodium valproateを使用した。

一一晚絶食後の Sprague-Dawly 系雄性ラット280 ～330 g の胃内にFLRX（10 $\mathrm{mg} / \mathrm{kg}$ 体重）と VPA $(400 \mathrm{mg} / \mathrm{kg}$ 体重）を同時に投与した．対照群の ラットにはVPAの代わりに0.5\% sodium carboxylmethylcellulose（CMC）を同量投与した。投与後 30分から24時間まで経時的に尾静脈より採血し， 高速液体クロマトグラフ（HPLC）法でFLRXを 定量した ${ }^{(6)}$. 薬物動態值は得られた血中濃度を (株)システムウェーブ社の PHAconet-one の 1 -コ ンパートメントモデル式に適用し，最小二乗法に より各パラメータを求めた。

$$
\begin{aligned}
\mathrm{C}(\mathrm{t})= & {[(\mathrm{D} \cdot \mathrm{F} \cdot \mathrm{Ka} / \mathrm{Vd}) /(\mathrm{Ka}-\mathrm{Ke})][\exp (-\mathrm{Ke}} \\
& \cdot \mathrm{T})-\exp (-\mathrm{Ka} \cdot \mathrm{T})]
\end{aligned}
$$

ここで, $\mathrm{C}(\mathrm{t})$ は投与後 $\mathrm{t}$ 時間後の FLRX 血漿 中濃度,また $\mathrm{Ke}$ は消失速度定数および $\mathrm{Ka}$ は吸 収速度定数, $\mathrm{Vd}$ はみかけの分布容積, D は投与 量，Tは時間，F は吸収率である。ただし消化管 からのVPAの吸収率はほぼ100\%であると報 告7.8)されていることから, $\mathrm{F}=1$ と仮定した。最 高血漿中濃度到達時間 $\left(\mathrm{T}_{\text {max }}\right)$, 最高血漿中薬物 濃度 $\left(\mathrm{C}_{\text {max }}\right)$, 血漿濃度-時間曲線下面積 $(\mathrm{AUC})$, クリアランス $(\mathrm{CL})$ は次式より求めた。

$$
\begin{aligned}
& \mathrm{T}_{\max }=[1 \mathrm{n}(\mathrm{Ka} / \mathrm{Ke})] /(\mathrm{Ka}-\mathrm{Ke}), \\
& \mathrm{C}_{\max }=(\mathrm{D} \cdot \mathrm{F} / \mathrm{Vd}) \cdot \exp \left(-\mathrm{Ke} \cdot \mathrm{T}_{\max }\right) \\
& \mathrm{AUC}=\int{ }^{24}{ }_{(1)} \mathrm{C}(\mathrm{t}) \mathrm{dt}+\mathrm{C}(24) / \mathrm{Ke}, \mathrm{CL}=\mathrm{D} / \mathrm{AUC}
\end{aligned}
$$

統計的解析は, student $の$ unpaired $\mathrm{t}$ 検定により 行い，いずれも $\mathrm{P}<0.050$ とき有意と判断した.

別の実験で FLRX (10mg/kg 体重) 投与 40 分後 のラットにVPA（100 mg/ $\mathrm{kg}$ 体重）を静注し，そ の直前， $2 ， 15,30$ 分後に頝静脈より採血し, 血 漿を centrifree (amicon) で1670×g，15分間遠心 限外万過を行い弓液中の FLRX 遊離薬物濃度を HPLC 法で測定した。また, FLRX $(10 \mathrm{mg} / \mathrm{kg}$ 体 重) と VPA $(400 \mathrm{mg} / \mathrm{kg}$ 体重) 同時投与 8 時間後 の尿中 FLRXの未変化体, demethyl 体, N-oxide 体を同様に HPLC 法で定量し対照群と比較検討 を行った(6).

\section{結果}

FLRX の血槳中濃度はVPA と同時に投与する とFLRX 単独投与時に比べて投与 30 分， 1 時間 後は有意に低く，2 時間後は対照群と同值を示し た。その後は逆転し，4，8，12，24時間值で有 意な上昇を認めた (Fig. 1)。薬物動態值はVPA を併用するとVdと AUC はそれぞれ1.2及び2.3 倍に有意に増加した。 $\mathrm{T}_{1 / 2}$ と $\mathrm{T}_{\text {max }}$ はそれぞれ 2.9 及 び2.6倍へと有意に遅延した，Ka と CL は $54 \%$ 及 び55\%有意に減少し。 $\mathrm{C}_{\text {max }}$ は20\%低下傾向を示し た（Table 1)。血漿に打ける非結合型FLRXの 割合（\%）はVPA 静注直前が54\%であったのに 対し, 静注 2 分後で $80 \% ， 15$ 分後で76\%に上昇し た。逆に，FLRX 結合型の割合（\%）はVPA 静 


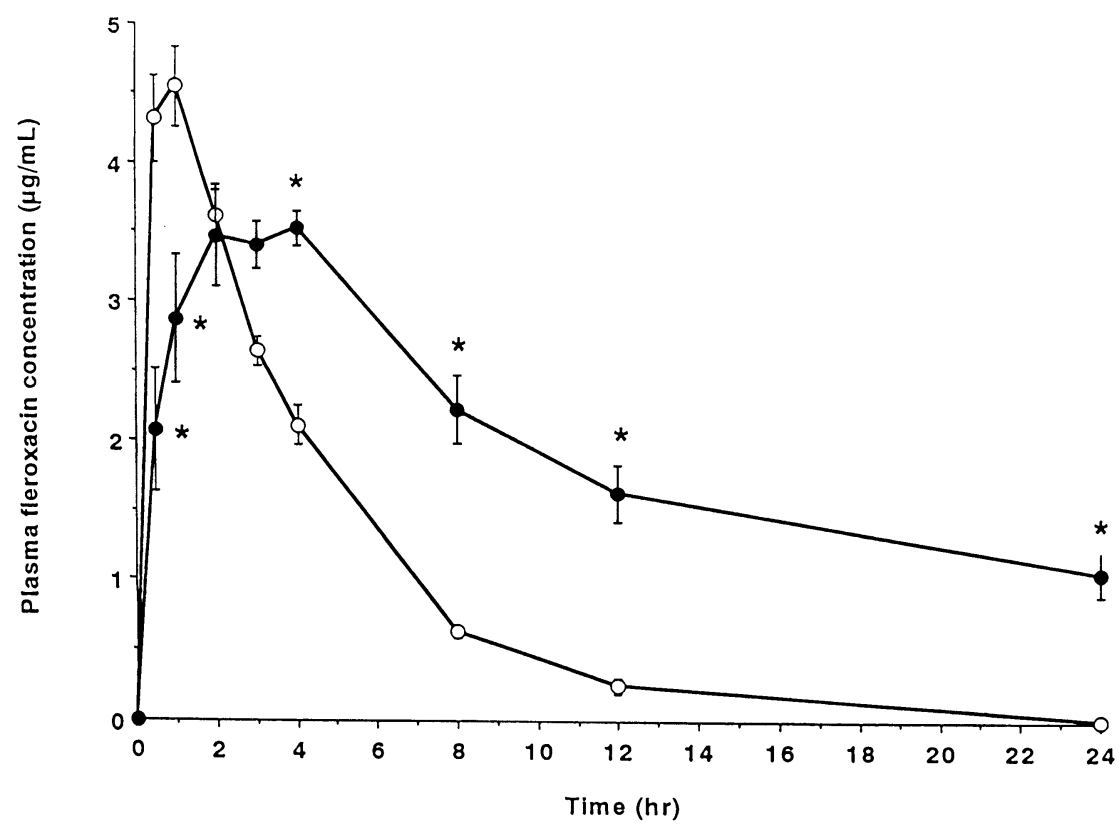

Fig. 1. Time Course of Plasma Fleroxacin Concentration Following Simultaneous Administration of $10 \mathrm{mg} / \mathrm{kg}$ Fleroxacin with CMC and with Sodium Valproate to Five, overnight Fasted Rats Vertical lines indicate SEM of the mean. $\quad * \mathrm{P}<0.05$

- - FLRX plus CMC ;

-FLRX plus sodium valproate

Table 1. Fleroxacin Pharmacokinetic Parameters in Rats after Simultaneous Administration of $10 \mathrm{mg} / \mathrm{kg}$ Fleroxacin Plus CMC or Plus $400 \mathrm{mg} / \mathrm{kg}$ Sodium Valproate

\begin{tabular}{lllccccc}
\hline $\begin{array}{l}\text { Parameters } \\
\text { (units) }\end{array}$ & $\begin{array}{c}\mathrm{Vd} \\
(\mathrm{L} / \mathrm{kg})\end{array}$ & $\begin{array}{l}\mathrm{T}_{1 / 2} \\
(\mathrm{~h})\end{array}$ & $\begin{array}{c}\mathrm{Ka} \\
\left(\mathrm{h}^{-1}\right)\end{array}$ & $\begin{array}{c}\mathrm{CL} \\
(\mathrm{L} / \mathrm{h} / \mathrm{kg})\end{array}$ & $\begin{array}{c}\mathrm{Tmax} \\
(\mathrm{h})\end{array}$ & $\begin{array}{c}\mathrm{Cmax} \\
(\mu \mathrm{g} / \mathrm{mL})\end{array}$ & $\begin{array}{c}\text { AUC } \\
(\mu \mathrm{g} \cdot \mathrm{h} / \mathrm{mL})\end{array}$ \\
\hline plus CMC & 5.68 & 2.59 & 3.35 & 1.53 & 0.82 & 4.63 & 21.42 \\
& \pm 0.50 & \pm 0.19 & \pm 0.14 & \pm 0.03 & \pm 0.03 & \pm 0.30 & \pm 1.49 \\
& & & & & & & \\
plus VPA & $7.38 *$ & $7.40 *$ & $1.55 *$ & $0.71 *$ & $2.14 *$ & 3.78 & $49.18 *$ \\
& \pm 0.38 & \pm 0.88 & \pm 0.31 & \pm 0.06 & \pm 0.44 & \pm 0.18 & \pm 4.07 \\
\hline
\end{tabular}

Each value is the mean $\pm S E M$ for 5 rats. $* P<0.05$

Vd; volume of distribution, $\quad T_{1 / 2}$; elimination half-time

$\mathrm{Ka}$; absorption constant, $\mathrm{CL}$; clearance Tmax; time to Cmax

Cmax; maximum plasma concentration

$\mathrm{AUC}_{0 \rightarrow 24}$; area under the plasma concentration-time curve to 24 hours

注直前が46\%であったのに対し2分後が 20.4\%，15分後が24.2\%に下降した（Fig. 2). 血漿中の総 FLRX 濃度は前值を $100 \%$ とすと 2 分後 $68.1 \%, 15$ 分後が $72.3 \%$ と低くなった. 8 時
間後の尿中 FLRXの未変化体, demethyl 体, Noxide 体は対照群でそれぞれ258.0，158.0，88.5 $\mu \mathrm{g} / \mathrm{ml}$ であったが，VPA投监羣では，それぞれ $122.5,93.0,43.0 \mu \mathrm{g} / \mathrm{ml}$ と低值をホした。 


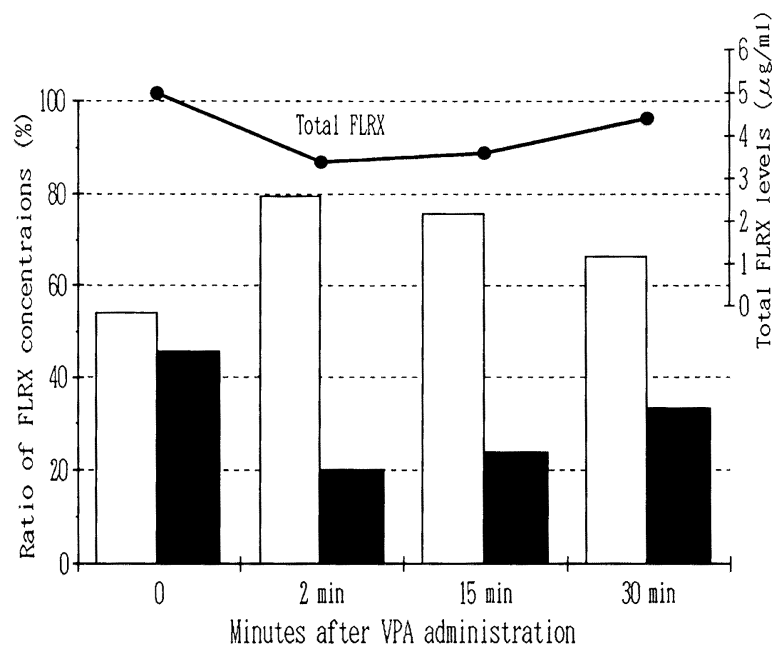

Fig. 2. Effect of Sodium Valproate on Fleroxacin Protein Binding Sodium Valproate $(100 \mathrm{mg} / \mathrm{kg})$ was Injected at 40 Minutes after Intragastrical Fleroxacin $(10 \mathrm{mg} / \mathrm{kg}$ ) Administration in Rat.

Blood samples were collected at $0,2,15$ and 30 minutes after injection of VPA. Determination of total and free plasma fleroxacin concentration described under materials and methods.

$\square$ Free FLRX; $\square$ Binding FLRX;

- Total FLRX concentration

\section{考察}

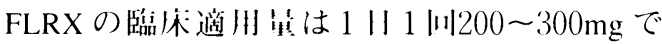

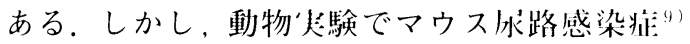

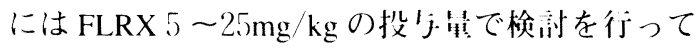
いる。また、ラットを川いた FLRXの体人動倿(”)の

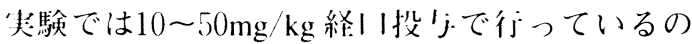
で、著者らの行った体历! kg 少たり $10 \mathrm{mg} の$ 経い

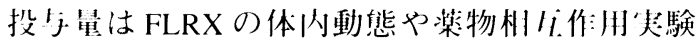
を動物で行う場介の通掌の適川㫣であると思われ た。また、VPAの臨休適用星は1 1 H 00 ～1200

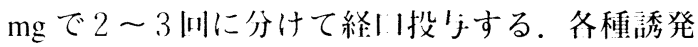

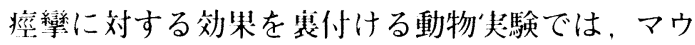
ス220〜 520mg/kg 経】投」j.で抑制を認めている. ラットでは100〜 700 mg/kg 経い投けで奏験を行 って，300 $\mathrm{mg} / \mathrm{kg}$ 以トの投! j例では全例強淔性属

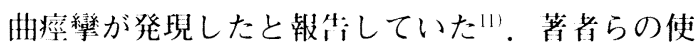
用した体重 $\mathrm{kg}$ 学たり $400 \mathrm{mg}$ は唀導倠戀を抑制す る薬理作用を小投投戊である。
VPA 同時投与後の FLRX 血漿中濃度が 2 時間 まで上昇しないのは，VPAによるFLRXの吸収 阻害とも考えられるので, FLRX単独投与時の $\mathrm{T}_{\text {max }} 0.82$ 時間より 8 分前の 40 分にVPA を静注す ると FLRXの総濃度は減少した。このことは VPA が血漿蛋白に結合している FLRX を追い出 し, 遊離型FLRX 濃度を増加させ, FLRXの組織 移行を促進する可能性が考えられた。そのため， VPA 同時投与後 2 時間までは FLRX が血漿中か ら組織へ移行するため, 血中濃度が対照群に比べ て有意に低くなり，FLRXの Vdの増加がこのこ とを示唆している成績と考えられた。

また, 組織への移行が終了したと考えられる 2 時間以後はVPAにより FLRX 代謝阻害の影響が より大きく現われ, 血漿中濃度が対照群に比べて 有意に高くなった。 FLRX 投与 2 時間以後の血中 濃度の有意な上昇と, $\mathrm{T}_{1 / 2}$ の延長と, 尿中の未変 化体, demethyl 体; N-oxide 体の減少はVPAによ るFLRX 代謝阻害である可能性を示唆した成績 
と考えられた。

今回は, 臨床使用量としては体重 $\mathrm{kg}$ 当たり VPA 400mg は高用量であるが, 動物実験では薬 理作用を示す用量であるので，動物を使用しての FLRX とVPAの併用により FLRXの組織内移行 の促進と代謝阻害を認めた成績を得たので, 臨床 で使用する際には注意が必要であろう.

\section{引用文献}

1) Keiji Hirai, Hiroshi Aoyama, Masaki Hosaka, Yasuo Oomori, Yasushi Niwata, Seigo Suzue and Tsutomu Irikura, Antimicrob. Agents Chemother., 29, 1059-1066 (1986).

2) Mitsuyoshi Nakashima, Toshihiko Uematsu, Yoshiharu Takiguchi, Atsuhiro Mizuno, Takehiko Itaya, Fumio Kawahara, Tsuyoshi Ooie, Shizuki Saito, Masaki Hosaka, Hiroshi Uchida and Kuniyoshi Masuzawa, J. Antimicrob. Chemother., 22, 133144 (1988).

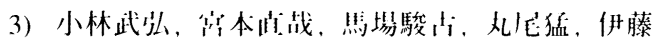
晴大，果内朗，Chemotherapy，38，641-648 (1990).

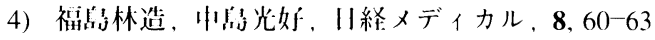
(1993)

5) Meunier, H., Carraz, G., Meunier, V. and M. Eymard, Therapie, 18, 435-438 (1963).

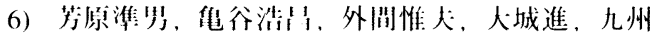
薬兴会会腩, 51, 9-15 (1997).

7) A.E. Stucke, F.J. Frey, P. Heizman, R. Brandt and E. Weidekamm, Antimicrob. Agents Chemother., 33, 373-381 (1989).

8) E. Weidekamm, R. Portmann, C. Partos, D. Dell and P.W. Lucker, Antimicroh. Agents Chemother. 31, 1909-1914 (1987).

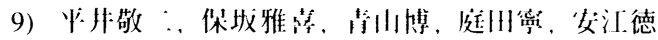

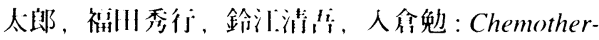
apy, 38, 80-85 (1990).

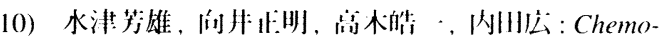
therapy, 38, 100-114 (1990).

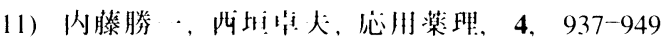
(1970) 